\title{
NOTES
}

\section{OVERLAP OF MOLT AND FALL MIGRATION OF THE WESTERN TANAGER AND WARBLING VIREO IN SOUTHERN CALIFORNIA}

\author{
PHILIP UNITT, LORI HARGROVE, and KEVIN B. CLARK, San Diego Natural \\ History Museum, P. O. Box 121390, San Diego, California 92112-1390; \\ birds@sdnhm.org
}

It is an axiom of ornithology that the energy-demanding phases of a small bird's life cycle, such as molt and migration, are segregated temporally (e.g., Newton 2008). This principle applies so widely that exceptions to it may be instructive. Here we report apparent exceptions in two species, the Warbling Vireo (Vireo gilvus) and Western Tanager (Piranga ludoviciana), on the basis of recent specimens from southern California.

A migratory bird may undergo its annual prebasic molt before or after migration. Molt after breeding but before long-distance migration is more common, but molt after migration, or at a stop during fall migration, is also widespread (Pyle et al. 2018). In passerines of western North America, molt after migration, or at a stop in the region of summer rain centering on northwestern mainland Mexico, predominates among the families Tyrannidae and Cardinalidae (Rohwer et al. 2005, Pyle et al. 2009). The age classes of a species may differ. If the first-year birds replace their juvenile plumage before departing their breeding range, the adults may molt after migration. Among the species in which the adults, after crossing the deserts, typically molt at a stop in the "Mexican monsoon region" are the Warbling Vireo and Western Tanager. The molt of both of these species with respect to migration has been studied thoroughly by Voelker and Rohwer (1998) and by Butler et al. (2002), respectively. Both species breed widely in forested regions of the western United States, from which they migrate to winter almost entirely in Mexico and Central America (the wintering of a few Western Tanagers in California has arisen only since urbanization and is essentially confined to urban landscaping with ample trees).

In southern California, migrating adult Western Tanagers begin appearing to the southeast of the species' breeding range in early July and are seen from mid-July through most of August in moderate numbers. Butler et al. (2002) reported that $24 \%$ of 175 adult Western Tanagers collected north of $30^{\circ} \mathrm{N}$ from 16 July onward had molted one or more flight feathers, but only $4 \%$ had replaced them all. They found that adults with substantial body molt were collected mostly in late August and early September-by which time nearly all adult Western Tanagers have already passed through southern California. Butler et al. (2002) concluded that, before they reach the monsoon region, Western Tanagers do not molt flight feathers and migrate simultaneously.

As one component of a study of wildlife use of inland wetlands in San Diego County, we mist-netted birds at three sites in 2017 and 2018. One of our five-day surveys at each site took place in late July or August when adult Western Tanagers and Warbling Vireos are migrating south through southern California: San Felipe Valley, 24-28 July 2017; Puerta la Cruz, 6-10 August 2017; and Clover Flat, 13-17 August 2018. These sites are oases of riparian vegetation at springs amid chaparral, grassland, and sagebrush, at elevations between 875 and $900 \mathrm{~m}$. Neither the Western Tanager nor the Warbling Vireo breeds or winters at either site (cf. Unitt 2004). At the latitude of these sites, the Western Tanager breeds at higher elevations, and the Warbling Vireo is restricted to a few remnant populations in more extensively wooded 
habitats (Unitt 2004). All three sites are near the eastern margin of the Peninsular Ranges, where migrating birds may stop before attempting a late-summer crossing of $\sim 500 \mathrm{~km}$ of desert to reach the monsoon region.

On dates from 8 to 15 August, we captured and collected five adult Western Tanagers two at Puerta La Cruz and three at Clover Flat. All were in light to moderate body molt, and two were replacing flight feathers (Table 1). A sample of five specimens is small, but that all five should be in body molt, and two in flight-feather molt, diverges widely from expectations based on the findings of Butler et al. (2002). Outside the Western Tanager's breeding range, north or west of extreme southern Arizona, Butler et al. (2002: figure 1B) mapped only one specimen (from along the Colorado River in southeastern California) that was molting flight feathers. Evidently this specimen is San Diego Natural History Museum (SDNHM) 33671, collected by May Canfield 2 miles north of Bard, Imperial County, on 16 August 1925 , in which primary 2 is growing.

The single Warbling Vireo we caught, at Clover Flat on 16 August 2018, was a female at least two years old (SDNHM 55908). It was molting primaries and rectrices. On both sides, primaries 1-3 were new, primary 4 was growing, and primaries 5-10 were old (Figure 1A). In the tail, rectrix pair 1 was fresh, pairs 2-4 were growing (4 just emerging from the sheath), and 5 and 6 were old and worn. In addition, body molt was moderate on the crown and light on the back, throat, and breast (Figure 1B). The bird was carrying a heavy load of fat.

The comprehensive study of the Warbling Vireo's molt by Voelker and Rohwer (1998) was based on 1228 specimens, from 26 museums, collected from 1 July to 31 December. They found no adult specimens of the western subspecies V. g. swainsoni collected northwest of Sonora to be replacing any flight feathers or to have completed body molt. They did, however, find several specimens from northwestern Mexico, some collected before 15 August, in active flight-feather molt. They concluded that adults of V. g. swainsoni undertake a molt-migration to northwestern Mexico before beginning flight-feather molt. By contrast, they found initiation though not completion of body molt in the breeding range to be widespread (58\% of 363 specimens from the western U.S. and southwestern Canada). They mapped several adult specimens from southeastern California, collected outside the breeding or winter range between

Table 1 Molt of Five Adult Western Tanagers from San Diego County, August 2017-2018

\begin{tabular}{|c|c|c|c|c|c|}
\hline & $\begin{array}{c}\text { SDNHM } \\
55238\end{array}$ & $\begin{array}{l}\text { SDNHM } \\
55243\end{array}$ & $\begin{array}{c}\text { SDNHM } \\
55896\end{array}$ & $\begin{array}{l}\text { SDNHM } \\
55903\end{array}$ & $\begin{array}{l}\text { SDNHM } \\
55904\end{array}$ \\
\hline Date & 8 Aug 2017 & 9 Aug 2017 & 14 Aug 2018 & 15 Aug 2018 & 15 Aug 2018 \\
\hline & female & male & female & female & female \\
\hline Locality & Puerta La Cruz & Puerta La Cruz & Clover Flat & Clover Flat & Clover Flat \\
\hline Body molt & $\begin{array}{l}\text { small patch on } \\
\text { breast; small } \\
\text { patch on nape/ } \\
\text { upper back }\end{array}$ & $\begin{array}{l}\text { light on crown } \\
\text { and breast; } 4 \\
\text { feathers on up- } \\
\text { per back }\end{array}$ & $\begin{array}{l}\text { scattered feath- } \\
\text { ers on forehead, } \\
\text { neck, and breast }\end{array}$ & $\begin{array}{l}\text { light on crown } \\
\text { and nape; a few } \\
\text { other scattered } \\
\text { body feathers }\end{array}$ & $\begin{array}{l}\text { Light in most } \\
\text { tracts of body } \\
\text { feathers, fairly } \\
\text { heavy on lower } \\
\text { throat and up- } \\
\text { per breast }\end{array}$ \\
\hline $\begin{array}{l}\text { Flight-feath- } \\
\text { er molt }\end{array}$ & none & none & none & $\begin{array}{l}\text { primary } 1, \text { left } \\
\text { side }\end{array}$ & $\begin{array}{l}\text { primaries } 1 \text { and } \\
2 \text { and rectrix } \\
\text { pair } 1 \text { growing }\end{array}$ \\
\hline Fat & $\begin{array}{l}\text { moderate to } \\
\text { heavy }\end{array}$ & heavy & heavy & heavy & heavy \\
\hline
\end{tabular}




\section{NOTES}

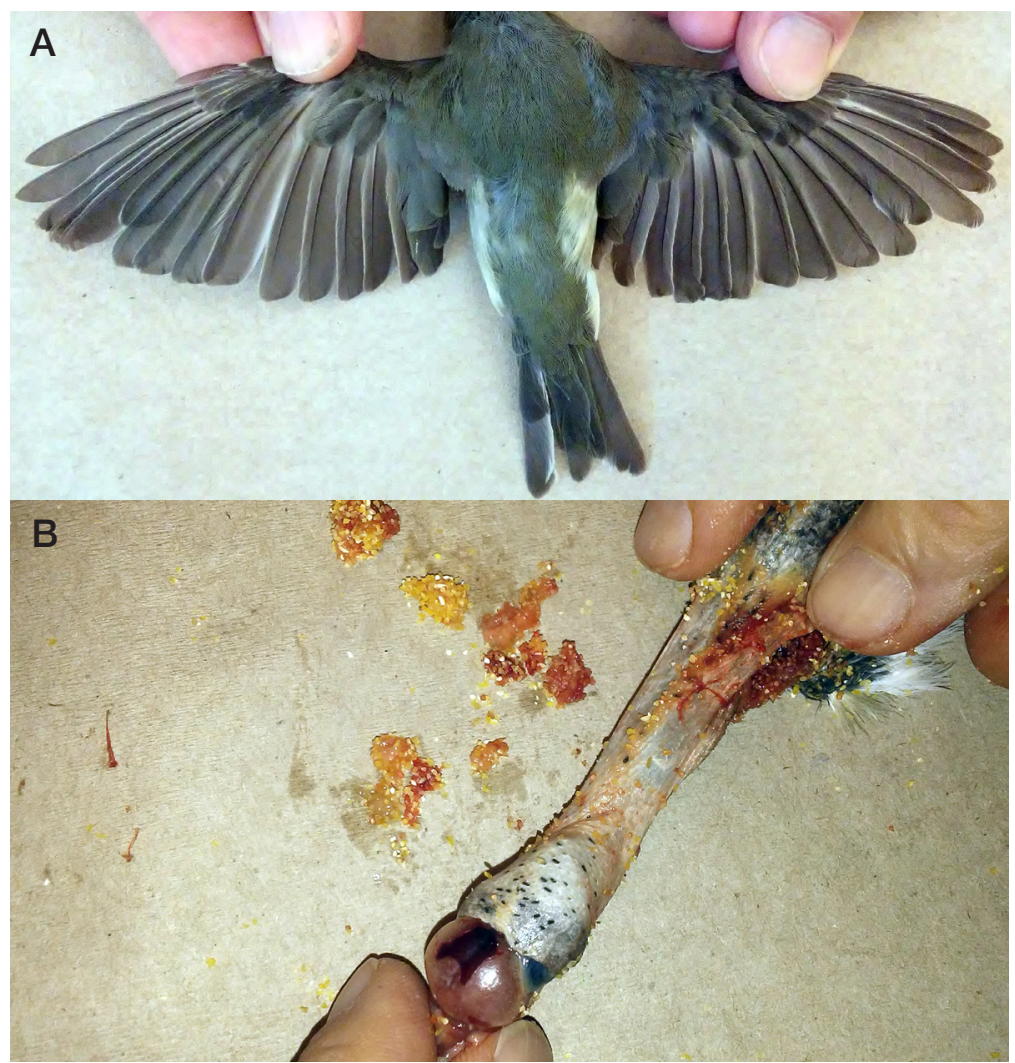

Figure 1. Adult Warbling Vireo from south-central San Diego County, California, 16 August 2018. (A) Dorsal view, showing molt of primaries (primary 4 growing) and rectrices (pairs 2-4 growing). (B) Inside of skin, showing moderate molt on crown and light molt on remainder of upperparts. Notice also the ample fat scraped off the skin.

1 July and 30 September, as in active body molt, and wrote, "thus far, swainsoni is the only vireo known to replace its body feathers during migratory flights" (p. 147).

Therefore these recent specimens of both the Western Tanager and Warbling Vireo from southern California represent stages of molt that should be expected only much farther southeast, on the opposite side of the Sonoran Desert in southeastern Arizona or northwestern mainland Mexico. One possibility for the atypical molt of these specimens is that they began or continued their molt in the middle of migration, in contradiction of the standard principle and previous evidence for these species. This possibility is supported by the birds' abundant reserves of fat, as typically found in both the Western Tanager and Warbling Vireo as they pass through southern California. In this case the specimens would represent "continuous moltmigration" as defined by Tonra and Reudink (2018:1127), previously unknown in these species.

One possibility is that these birds had been somehow delayed in migration until the time intrinsic or extrinsic stimuli triggered the onset of molt. But many 
specimens in molt have been collected later in the year, after 16 August (Voelker and Rohwer 1998, Butler et al. 2002), negating this possibility.

Another possibility is that these birds had cut their breeding season short and moved on to the next stage in their life cycle earlier than is typical. In years of severe drought, as prevailed in southern California from 2013 to 2018, nesting of land birds in southern California typically ends early in the summer (if it takes place at all; Bolger et al. 2005), and the molt that follows also can begin earlier than in wet years. This pattern is seen in sedentary species such as the California Towhee (Melozone crissalis; Unitt pers. obs.) and species that molt before migration such as Bell's Vireo (Vireo bellii; Clark pers. obs.). But whether it prevails in species that molt after migration, or at an intermediate stop, has not been investigated.

Perhaps the most likely possibility is that these Western Tanagers and Warbling Vireo had stopped to complete their molt, as if they had reached Sonora, even though a stop for molt in southern California by these species is previously unknown.

The Western Tanager and Warbling Vireo are considered exemplars of species that complete most or all of their molt south of the breeding range in the region centering on northwestern mainland Mexico that receives monsoon rain in summer. Even though summer thundershowers are occasional in the mountains of southern California, on average they represent a minor fraction of the region's precipitation, which falls largely from November to April. Southern California has never been considered part of the "monsoon region." Yet the specimens we report here were molting as if they had reached it. Therefore the birds may have been stimulated by unusual or novel factors that mimic those in northwestern mainland Mexico.

Since 2014, summer ocean temperatures along the southern California coast have been unusually warm, contributing to increased humidity in the region. In late July and early August 2018, a succession of record ocean temperatures at La Jolla peaked at $26.4^{\circ} \mathrm{C}$ on 9 August (Carter et al. 2019; https://scripps.ucsd.edu/programs/ shorestations/shore-stations-data/data-sio/). In the mountains of San Diego County to the east, in the region where these tanagers and vireo were collected, the weather was also hot and humid. On the basis of data for 1993 through 2018 from six stations (Ranchita, Julian, Descanso, Mount Laguna, Cameron Fire Station, and Potrero) combined, 2017 and 2018 were two of only four years in which both the average temperature in July was above $24^{\circ} \mathrm{C}$ and the relative humidity in July was above $45 \%$ (data from https://raws.dri.edu/wraws/scaF.html, downloaded September 2019). Longer-term humidity data for this region are not available, but at Henshaw Dam, a nearby station for which temperature data are available from 1943 onward, the average July temperature from 1943 to 2000 was $22.4^{\circ} \mathrm{C}$. In 2017 and 2018 it was $24.5^{\circ} \mathrm{C}$ and $25.5^{\circ} \mathrm{C}$, respectively. The 2018 value was the highest on record. At Campo, just $7 \mathrm{~km}$ southwest of Clover Flat, the precipitation in July and August 2018, $27.2 \mathrm{~mm}$, was over double the average of the preceding 20 years, $12.9 \mathrm{~mm}$.

Climate change should affect all aspects of a bird's biology, but very few studies have addressed its effects on molt (Seavy et al. 2018). Taylor et al. (2018) reported an increase in the duration of molt in the Dunlin (Calidris alpina) in Alaska. In the Netherlands, Jukema and Wiersma (2014) found a shift toward earlier molt of primaries in the Eurasian Golden Plover (Pluvialis apricaria) and Tomotani et al. (2017) found a shift toward earlier molt in the Pied Flycatcher (Ficedula hypoleuca). Kiat et al. (2019) reported a trend toward more extensive post-juvenile molt in 19 species of western palearctic thrushes, flycatchers, and shrikes. Our observations of atypical molt in the Western Tanager and Warbling Vireo, however, may represent climate change leading to a shift in location of molt. Predictions for the future climate of southern California's mountains include also hotter and wetter summers. In California, heat waves characterized by high humidity and high nighttime temperatures, such as that of late July-early August 2018, have increased in the $21^{\text {st }}$ century (Gershunov and Guirguis 2012). Though Gershunov and Guirguis (2012) projected 


\section{NOTES}

both humid and dry heat waves to increase, their models indicate that the humid heat waves will increase disproportionately.

After capturing and assessing the molt of fall migrants from 1 July to 9 October over two years at 13 sites in southeastern Arizona, Sonora, and Sinaloa, Pyle et al. (2009) found that the fidelity of such molt migrants to sites of molting is low. They concluded that the sites of these birds' molts are flexible, varying with varying environmental conditions. Apparently, this flexibility may include molting at a point along the path of migration far short of the Mexican monsoon region as previously understood. Modeling (Figure S1 in Pyle et al. 2018) suggests that the Western Tanager and Warbling Vireo are more likely to molt than to breed in southeastern California, but on the basis of extrapolation from few records from a few banding stations lying largely outside the breeding range of both species.

If the site of molt-migrants' molt is as flexible as Pyle et al. (2009) suggested, the issue of climate change inducing a phenological mismatch between supply and demand may be less for molt than it is for breeding. But the proximal stimuli for molt may differ from the conditions that generate a flush of insects sufficient to fuel an insectivorous bird's molt. Summer rain in southern California must increase greatly and become far more reliable before it replicates conditions in the monsoon region. And the prediction for California's future precipitation is increased variability (Swain et al. 2018), so a bird could well be stimulated to molt in southern California one year but not the next.

The importance of riparian oases as resources for migrating birds that must cross deserts is widely known. In southeastern Arizona, Chambers et al. (2011) found molt-migrants tending to congregate in riparian habitat, especially in drier years. If molt is a burden additional to accumulating the fat needed to make a long nonstop flight across the desert in late summer, however, then the value of these oases as critical resources in southern California is even greater than previously appreciated.

Thank you to the California Department of Fish and Wildlife for sponsoring the San Diego Natural History Museum's study of wildlife use of inland wetlands. And for authorizing collection of specimens as part of the study, enabling a deeper understanding of that use. Thank you to Hans Sin of the California Department of Fish and Wildlife for coordinating the contract, and thank you to the Vista Irrigation District and the Back Country Land Trust for authorizing work at Puerta La Cruz and Clover Flat, respectively. Thank you to Elisa Yang and Lea Squires for their help in the field. Thank you to Peter Pyle, Ryan Terrill, and Daniel D. Gibson for their helpful reviews of the manuscript.

\section{LITERATURE CITED}

Bolger, D. T., Patten, M. A., and Bostock, D. C. 2005. Avian reproductive failure in response to an extreme climatic event. Oecologia 142:398-406; doi 10.1007/ s00442-004-1734-9.

Butler, L. K., Donahue, M. G., and Rohwer, S. 2002. Molt-migration in Western Tanagers (Piranga ludoviciana): Age effects, aerodynamics, and conservation implications. Auk 119:1010-1023; doi 10.1093/auk/119.4.1010.

Carter, M. L., Fumo, J. T., McGowan, J. A., Terrill, E., and Flick, R. E. 2019. Surface water temperatures and salinities at shore stations. California. 2018. Scripps Inst. Oceanogr., Univ. Calif., La Jolla; https://scripps.ucsd.edu/programs/ shorestations/wp-content/uploads/sites/96/2019/08/2018-Shore-StationsAnnual-Report.pdf.

Chambers, M., David, G., Ray, C., Leitner, B., and Pyle, P. 2011. Habitats and conservation of molt-migrant birds in southeastern Arizona. Southwest. Nat. 56:204-211; doi 10.1894/F09-KF-13.1.

Gershunov, A., and Guirguis, K. 2012. California heat waves in the present and 


\section{NOTES}

future. Geophys. Res. Lett. 39:L18710; doi 10.1029/2012GL052979.

Jukema, J., and Wiersma, P. 2014. Climate change and advanced primary moult in Eurasian Golden Plovers Pluvialis apricaria. Ardea 102:153-159; doi 10.5253/ arde.v102i2.a5.

Kiat, Y., Vortman, Y., and Sapir, N. 2019. Feather moult and bird appearance are correlated with global warming over the last 200 years. Nat. Commun. 10(2540); doi 10.1038/s41467-019-10452-1.

Newton, I. 2008. The Migration Ecology of Birds. Academic Press, Amsterdam.

Pyle, P., Leitner, W. A., Lozano-Angulo, L., Avilez-Teran, F., Swanson, H., GómezLimón, E., and Chambers, M. K. 2009. Temporal, spatial, and annual variation in the occurrence of molt-migrant passerines in the Mexican monsoon region. Condor 111:583-590; doi 10.1525/cond.2009.090085.

Pyle, P., Saracco, J. F., and DeSante, D. F. 2018. Evidence of widespread movements from breeding to molting grounds by North American landbirds. Auk 135:506-520; doi 10.1642/AUK-17-201.1.

Rohwer, S., Butler, L. K., and Froehlich, D. 2005. Ecology and demography of eastwest differences in molt scheduling of neotropical migrant passerines, in Birds of Two Worlds: The Ecology and Evolution of Migratory Birds (R. Greenberg and P. P. Marra, eds.), pp. 87-105. Johns Hopkins Univ. Press, Baltimore.

Seavy, N. E., Humple, D. L., Cormier, J. R., Porzig, E. L., and Gardali, T. 2018. Evidence of the effects of climate change on landbirds in western North America: A review and recommendations for future research, in Trends and traditions: Avifaunal change in western North America (W. D. Shuford, R. E. Gill Jr., and C. M. Handel, eds.), pp. 331-343. Studies of Western Birds 3. W. Field Ornithol., Camarillo, CA; doi 10.21199/SWB3.18.

Swain, D. L., Langenbrunner, B., Neelin, J. D., and Hall, A. 2018. Increasing precipitation volatility in twenty-first century California. Nature Climate Change 8:427-433.

Taylor, A. R., Lanctot, R. B., and Holmes, R. T. 2018. An evaluation of 60 years of shorebird response to environmental change at Utqiagvik (Barrow), Alaska, in Trends and traditions: Avifaunal change in western North America (W. D. Shuford, R. E. Gill Jr., and C. M. Handel, eds.), pp. 312-330. Studies of Western Birds 3. W. Field Ornithol., Camarillo, CA; doi 10.21199/SWB3.17.

Tomotani, B. M., van der Jeugd, H., Gienapp, P., de la Hera, I., Pilzecker, J., Teichmann, C., and Visser, M. E. 2017. Climate change leads to differential shifts in the timing of annual cycle changes in a migratory bird. Global Change Biol. 24:823-835; doi 10.1111/gcb.14006.

Tonra, C. M., and Reudink, M. W. 2018. Expanding the traditional definition of molt-migration. Auk 135:1123-1132; doi 10.1642/AUK-17-187.1.

Unitt, P. 2004. San Diego County bird atlas. Proc. San Diego Soc. Nat. Hist. 39.

Voelker, G., and Rohwer, S. 1998. Contrasts in scheduling of molt and migration in eastern and western Warbling Vireos. Auk 115:142-155; doi 10.2307/4089119.

Accepted 12 December 2019 